\section{FAMÍLIA NA CONTEMPORANEIDADE: mudanças e permanências}

SINGLY, François de. Sociologia da família contemporânea. Trad. Clarice Ehlers Peixoto. Rio de Janeiro: Editora FGV, 2007. 208 p. (Família, geração \& cultura).

\section{Carolina M. B. de Souza}

Ao longo das últimas décadas o debate sobre a crise da família, no Ocidente, foi propiciado pelos efeitos da generalizada aceitação social do divórcio, do declínio da instituição do casamento e da baixa taxa de fecundidade. Esses acontecimentos tanto indicaram a compreensão de que se delineara o enfraquecimento da família, quanto sugeriram a análise do surgimento de novos modelos familiares, caracterizados, por sua vez, pelas mudanças nas relações entre os sexos e as gerações, tais como: controle mais intenso da natalidade, autonomia relativa da sexualidade referente à esfera conjugal (posto que o exercício da atividade sexual deixa de estar circunscrito à esfera do matrimônio), inserção massiva da mulher no mercado de trabalho, questionamento da autoridade paternal, atenção ao desenvolvimento das necessidades infantis e dos idosos, entre outras.

Essa segunda vertente de entendimento éa perspectiva condutora das análises de Singly (2007) em Sociologia da família contemporânea, que aborda a individualização das relações familiares, especificamente na França, estabelecendo associações entre as mudanças da modernidade e seus efeitos na família. O autor, que dirige o Centre d'Études sur les Liens Sociaux (Centro de Estudos sobre os Laços Sociais), em suas pesquisas, focaliza os comportamentos interpessoais no âmbito conjugal, procurando demonstrar que, nas sociedades contemporâneas ocidentais, os indivíduos não se parecem com aqueles das gerações precedentes, de- vido ao surgimento do indivíduo original e autônomo, resultante da imposição dessas sociedades, as quais fazem vigorar razões tanto ideológicas quanto objetivas. Salienta que a procura de si não traduz, primordialmente, narcisismo; solicita, contrariamente, destaque do olhar dos outros. Considera a dimensão relacional presente no processo constitutivo da identidade pessoal dos indivíduos, em que os outros significativos são, em geral e prioritariamente, o cônjuge ou o parceiro para um homem ou uma mulher, os pais para os filhos e reciprocamente.

O livro compõe-se de três partes. Singly visa a elucidar a família contemporânea, demonstrando sua dependência em relação ao Estado (parte I) e sua independência quanto aos grupos de parentesco (parte II) e à família (parte III). Os argumentos apresentados em seu desenrolar examinam algumas características: a família contemporânea é relacional, é privada e pública, é individualista e precisa de horizonte intergeracional - eixos norteadores através dos quais explicita suas idéias.

A característica referente ao duplo movimento da família contemporânea de ser privada e, ao mesmo tempo, pública, é destacada pelo autor, que apreende a família como um espaço no qual os indivíduos acreditam proteger a sua individualidade, ao tempo em que sofrem intervenção do Estado mediante o apoio e a regulação sobre as relações dos seus componentes - como exemplo, refere-se à criação de leis que objetivam limitar o direito da punição paternal.

Os argumentos apresentados no desenvolvimento do livro remetem à idéia central de Singly - a família contemporânea se define mais pelas relações internas travadas no cerne familiar e menos como instituição. O ponto em comum existente entre a família antiga e a família moderna, na compreensão do autor, consiste em contribuir para a função da reprodução biológica e social da sociedade, e ambas procuram manter e melhorar a posição da família no espaço social de uma geração a outra. O autor, que formula uma abordagem sociológica da percepção de como se expressam sentimentos e emoções no âmbito da família durante o 
século XX, destaca a predominância, a partir da segunda metade desse século, de relações menos hierarquizadas, quer entre o casal, quer entre pais e filhos - ambas sob o olhar atento dos agentes do Estado (demógrafos, psicólogos, assistentes sociais e sociólogos). Assinala, todavia, que os conflitos não deixam de existir no contexto familiar.

"A dependência da família em relação ao Estado" é o título da Parte I de Sociologia da Família Contemporânea, em que Singly examina detalhadamente as relações travadas entre Estado, escola e família. Nesse sentido, reflete sobre análises de Parsons, contrapondo-se à sua idéia, predominante na sociedade norte-americana nos anos 1950, de que toda responsabilidade assumida pela instituição escolar é retirada da família. Na tentativa de elucidar os elos existentes entre a família e a escola, Singly ratifica algumas concepções de Àries (1981), como aquela de que as preocupações educativas são pilares norteadores da família moderna, e de Bourdieu (1996), ao salientar a predominância do capital escolar nas sociedades contemporâneas.

Um esboço da tendência geral dos processos de formação familiar pelas novas gerações é traçado por Singly na segunda parte da obra, ressaltando o desuso da recorrência aos casamentos arranjados e questionando se as alianças são seladas apenas pelo amor e pelo desinteresse. $\mathrm{O}$ autor utiliza, então, o conceito de capital cultural formulado por Bourdieu para apreender algumas mediações que tornam possível o amor desinteressado e a defesa dos interesses sociais - o corpo e o caráter revelam os capitais escolares e sociais.

Singly demarca que o período contemporâneo se caracteriza pelo maior domínio do destino individual e familiar, devido a um sistema de valores que aprova a autonomia e a recusa dos indivíduos em seguirem costumes referentes ao desempenho dos papéis sociais de marido e esposa, das gerações passadas. Consequentemente, ocorre o duplo movimento - recusar a instituição do casamento e criticar a divisão do trabalho entre os sexos. Menciona, como exemplo, as condições objetivas que permitem o controle desse domínio in- dividual, especialmente as técnicas modernas de controle dos nascimentos.

Considera que as transformações da família têm uma grande coerência, embora deem a impressão de certa desordem e de uma incerteza, que poderiam preocupar. Singly destaca que a história da família contemporânea pode ser dividida em dois períodos. Assinala a evidência verificada em todos os meios sociais, durante meio século (19181968), do fato de o homem trabalhar fora para ganhar o dinheiro da família e de a mulher ficar em casa para se ocupar, o melhor possível, dos filhos. Essa tipologia familiar é designada, pelo autor, de família moderna 1, ou da primeira modernidadeestá centrada no grupo, e os adultos estão a serviço da família e, principalmente, das crianças. A partir dos anos 1960, quando a modernidade na Europa muda de direção e entra no período denominado por Giddens (1991) de "modernidade avançada”, a família atribui peso ao processo de individualização. Singly qualifica essa segunda tipologia familiar de família moderna 2.

A diversidade das formas familiares e a menor estabilidade da vida conjugal não devem induzir a um diagnóstico errôneo, na elucidação de Singly, que constata, em suas pesquisas, o ideal da vida conjugal para um grande número de pessoas. Contrariamente ao celibato ou à vida solitária, a vida conjugal é mais atrativa, pois assegura a impressão de que não se é somente um personagem público ou um indivíduo que deve viver, sobretudo, segundo a lógica do interesse e das relações de competição que dominam a esfera do trabalho.

O triplo movimento da segunda fase da família contemporânea, do ponto de vista das relações entre os sexos, é assinalado por Singly: diminuição sensível da dependência objetiva da mulher, manutenção dos investimentos profissionais e domésticos diferenciados segundo o sexo e fuga dos papéis sexuais que surgiram com o compromisso conjugal.

No entender do autor, o movimento de individualização que perpassa as relações conjugais encontra-se inacabado, indicando a permanência das desigualdades do trabalho doméstico, de- 
vido à atribuição desse trabalho às mulheres, bem como a exclusão dos homossexuais do casamento. Considera que as sociedades ocidentais não seguem nem seguirão um processo similar de etapas, o que não significa que elas estejam ao largo da modernidade - entendida sob a perspectiva da individualização.

Reflete, enfim, que, tal como a modernidade, a família se define por um futuro incerto, pois, embora os entraves e constrangimentos sociais estejam presentes, os indivíduos constroem suas histórias.

(Recebido para publicação em outubro de 2008) (Aceito em dezembro de 2008)

\section{REFERÊNCIAS}

ÀRIES, Philippe. História social da criança e da família. Rio de Janeiro: LTC, 1981. 234p.

BOURDIEU, Pierre. Razões práticas: sobre a teoria da ação. Campinas, SP: Papirus, 1996. 224p.

CICHELLI, Vincenzo; PEIXOTO, Clarice Ehlers; SINGLY, François de. Família e individualização. Rio de Janeiro: Editora FGV, 2000. 200p.

GIDDENS, Anthony. Conseqüências da modernidade. São Paulo: Ed. Universidade Federal Paulista, 1991. 177p.

Carolina M. B. de Souza. Socióloga, doutoranda em Ciências Sociais pelo Programa de PósGraduação em Ciências Sociais da UFBA e professora substituta do Departamento de Ciências Humanas e Filosofia da UEFS. carolinamarback@yahoo.com.br. 